\title{
MANAJEMEN PENYELESAIAN PEMBIAYAAN BERMASALAH PADA LEMBAGA PERBANKAN SYARIAH
}

\author{
Muhamad Turmudi \\ Dosen Fakultas Ekonomi dan Bisnis Islam IAIN Kendari \\ E-mail: muhamad_turmudi@yahoo.co.id
}

\begin{abstract}
Islamic financing products divided into three categories; (1) financing using the principle of trading is distinguished by a form of payment and delivery time of goods. Products related to the sale and purchase agreement is financing murabaha, salam and istishna (2) financing lease using the principle is implemented in form ijaroh and ijaroh muntahiya bittamlik (3) financing using profit sharing principle is implemented in form of financing and Musharaka. Bank Indonesia Regulation No.7/2/PBI/2005 classify the credit quality assessment become current, special mention, substandard, doubtful and jammed. Financing is a product that has a high risk level, as to prevent any risk of financing can apply the standards of risk control and analyze carakter, capacity, capital, collateral, condition, sharia or analysts personalty, party, perpose, prosfect, payment, profitability, protection before realizing financing. In the event of any financing problems, the remedies can be done in the form of restructuring, settlement through a guarantee or write off.
\end{abstract}

Keywords: Islamic finance, control and prevention of financial risks, efforts to resolve the financing problems.

A. Pendahuluan

Bank merupakan lembaga keuangan yang berfungsi sebagai perantara keuangan antara pihak yang berkelebihan dana dan pihak yang kekurangan dana. Melalui bank, kelebihan dana tersebut dapat disalurkan kepada pihak-pihak yang memerlukan dan memberikan manfaat bagi kedua belah pihak. Bank menerima simpanan uang dari masyarakat (dana pihak ketiga) dan kemudian menyalurkannya kembali dalam bentuk kredit (Sinungan, 2000: 6). Secara spesifik fungsi bank dapat sebagai agent of trust, agent of development, serta agent of services (Triandaru, 2006: 16).

Sebagai lembaga penghimpun dan penyalur dana, tugas tersebut sangat diperlukan untuk kelancaran kegiatan perekonomian disektor riil, sehingga memungkinkan masyarakat untuk berinvestasi, distribusi dan konsumsi yang berimbas pada kegiatan pembangunan perekonomian masyarakat. Sehingga bank berperan sebagai agen pembangunan yang bertujuan menunjang pelaksanaan pembangunan nasional dalam rangka meningkatkan pemerataan, pertumbuhan ekonomi dan stabilitas nasional kearah peningkatan kesejahteraan rakyat banyak (Djumhana, 2000: 3).

Pertumbuhan perekonomian membutuhkan modal yang cukup besar sehingga bank diharapkan mampu memberikan pembiayaan yang 
sebaiknya diperoleh dari sumber dana melalui mobilisasi dana masyarakat. Pertumbuhan ekonomi tersebut harus diarahkan untuk meningkatkan perekonomian masyarakat sehingga perlu adanya kemudahan pembiayaan bagi pelaku usaha mikro.

Namuan demikian, sebagai agent of trust, dalam melaksanakan kegiatannya baik sebagai penghimpun dana maupun penyaluran dana selalu berdasarkan kepercayaan. Masyarakat percaya bahwa uangnya tidak akan disalahgunakan oleh bank, uangnya akan dikelola dengan baik, bank tidak akan bangkrut, dan juga percaya bahwa pada saat yang telah dijanjikan masyarakat dapat menarik lagi simpanan dananya di bank. Pihak bank sendiri akan mau menempatkan atau menyalurkan dananya pada debitur atau masyarakat apabila dilandasi unsur kepercayaan bahwa debitur tidak akan menyalahgunakan pinjamannya, debitur akan mengelola dana pinjamannya dengan baik, debitur akan mempunyai kemampuan untuk membayar pada saat jatuh tempo, dan bank juga percaya bahwa debitur mempunyai niat baik untuk mengembalikan pinjaman beserta kewajiban lainnya pada saat jatuh tempo (Triandaru, 2006: 16).

Perkembangan

industri

keuangan syariah sudah ada sebelum adanya perundang-undangan mengenai bank syariah, hal tersebut dibuktikan dengan adanya badan usaha pembiayaan non-bank yang telah menerapkan konsep bagi hasil dalam kegiatan oprasionalnya sejak sebelum tahun 1992, hal tersebut menunjukkan kebutuhan masyarakat akan hadirnya institusi-institusi keuangan yang dapat memberikan jasa keuangan yang sesuai dengan syariah (Sutedi, 2009: v). Untuk memenuhi kebutuhan masyarakat tersebut, pemerintah mengeluarkan UU No. 7 Tahun 1992 tentang Perbankan yang membuka peluang bagi kegiatan usaha bank yang memiliki dasar oprasional bagi hasil dan dijabarkan dalam PP No. 72 Tahun 1992 Tentang Bank Berdasarkan Prinsip Bagi Hasil. Perbankan syari'ah pada dasarnya merupakan suatu industri keuangan yang memiliki sejumlah perbedaan mendasar dalam kegiatan usahanya dibanding perbankan konvensional, perbedaan keduanya terletak pada prinsip operasional yang digunakan. Bank syari'ah beroperasi berdasarkan prinsip bagi hasil sedangkan bank konvensional berdasarkan prinsip bunga. Prinsip bunga dalam menghimpun dana ataupun menyalurkannya dalam bentuk kredit/pembiayaan dikatagorikan riba dalam sistem ekonomi Islam yang sudah jelas larangannya.

Secara garis besar bank syariah memiliki 3 (tiga) bentuk kegiatan operasional, yaitu:

1. Kegiatan penghimpunan dana (funding). Kegiatan penghimpunan dana dapat ditempuh oleh perbankan melalui mekanisme tabungan, giro, serta deposito.

2. Kegiatan penyaluran dana (lending). Kegiatan penyaluran dana kepada masyarakat (lending) dapat ditempuh bank dalam bentuk mudharabah, murabaha, musyarakah, ijarah ataupun qardh.

3. Jasa Bank. Kegiatan usaha bank di bidang jasa, dapat berupa penyediaan bank garansi (kafalah), letter of credit (L/C), hiwalah, wakalah dan jual beli valuta asing (Anshori, 2007: 65). 
Dalam operasionalnya, lembaga keuangan perbankan tidak terlepas dari berbagai jenis risiko sebagai berikut:

1. Risiko Modal (capital risk). Risiko modal (capital risk) merupakan risiko yang merefleksikan tingkat leverage yang dipakai oleh bank.

2. Risiko Likuiditas. Risiko likuiditas antara lain disebabkan bank tidak mampu memenuhi kewajiban yang telah jatuh tempo. Bank memiliki dua sumber utama bagi likuiditasnya, yaitu aset dan liabilitas.

3. Risiko Kredit/ Pembiayaan. Resiko kredit muncul jika bank tidak bisa memperoleh kembali cicilan pokok dan atau bunga dari pinjaman yang diberikannya atau investasi yang sedang dilakukannya.

4. Risiko Pasar. Resiko pasar adalah risiko kerugian yang dapat dialami bank melalui portofolio yang dimilikinya sebagai akibat pergerakan variabel pasar (adverse movement) yang tidak menguntungkan.

5. Risiko Operasional. Resiko operasional adalah resiko akibat kurangnya (deficiencies) sistem informasi atau sistem pengawasan internal yang akan menghasilkan kerugian yang tidak diharapkan.

6. Risiko Hukum. Resiko hukum adalah terkait dengan resiko bank yang menanggung kerugian sebagai akibat adanya tuntutan hukum, kelemahan dalam aspek legal atau yuridis.

7. Risiko Reputasi. Resiko reputasi adalah resiko yang timbul akibat adanya publikasi negatif yang terkait dengan kegiatan usaha bank atau karena adanya persepsi negatif terhadap bank (Arifin, 2005: 60)

\section{B. Pembiayaan}

Dalam sistem perbankan syariah tidaklah dikenal istilah kredit dan bunga. Secara umum, di bank syariah menggunakan skema jual beli dan pembiayaan dengan bagi hasil. Peraturan perundang-undangan Republik Indonesia tentang perbankan meskipun tidak langsung mengatur mengenai penghapusan bunga, akan tetapi telah memberi tempat tumbuhnya alternative lain selain bunga. Dalam UU No. 21 Tahun 2008 Pasal 1 Butir 25 huruf a secara eksplisit menyatakan adanya frase imbalan atau bagi hasil sebagai manfaat yang bisa diambil bank dari skema pembiayaan berdasarkan prinsip syari'ah. Pasal 1 tersebut menyatakan bahwa pembiayaan adalah penyediaan dana atau tagihan yang dipersamakan dengan itu, berupa:

1. Transaksi bagi hasil dalam bentuk mudarabah dan musyarakah;

2. Transaksi sewa-menyewa dalam bentuk ijarah atau sewa beli dan dalam bentuk ijarah muntahiya bittamlik;

3. Transaksi jual beli dalam bentuk piutang murabahah, salam dan istisna;

4. Transaksi pinjam-meminjam dalam bentuk piutang qardh;

5. Transaksi sewa menyewa jasa dalam bentuk ijarah untuk transaksi multijasa berdasarkan persetujuan dan kesepakatan antara bank syari'ah dan/atau unit usaha syari'ah dan pihak lain yang mewajibkan pihak yang dibiayai dan/atau diberi fasilitas dana untuk mengembalikan 
dana tersebut setelah jangka waktu tertentu dengan imbalan ujrah, tanpa imbalan atau bagi hasil (Sutedi, 2009: 67).

Penyaluran dana dalam sistem perbankan syari'ah dikenal dengan pembiayaan berdasarkan prinsip syari'ah yang didefinisikan sebagai penyediaan uang atau tagihan yang dapat dipersamakan dengan itu berdasarkan persetujuan atau kesepakatan antar bank dengan pihak lain yang mewajibkan pihak yang dibiayai untuk mengembalikan uang atau tagihan tersebut setelah jangka waktu tertentu dengan dengan imbalan atau bagi hasil (Anshori, 2008: 53).

Pembiayaan merupakan salah satu produk perbankan syariah yang berupa penyaluran dana kepada nasabah (debitur) baik untuk keperluan produktif maupun konsumtif. Pembiayaan diartikan sebagai suatu kegiatan pemberian fasilitas keuangan/finansial yang diberikan satu pihak kepada pihak lain untuk mendukung kelancaran usaha maupun untuk investasi yang telah direncanakan. Pembiayaan merupakan salah satu tugas pokok bank, yaitu pemberian fasilitas penyediaan dana untuk memenuhi kebutuhan pihak-pihak yang merupakan deficit unit (Antonio, 2001: 168).

Dalam pelaksanaannya, pembiayaan bank syariah harus memenuhi dua aspek yaitu syar'i dan aspek ekonomi. Yang dimaksud dengan aspek syar'i adalah setiap realisasi pembiayaan kepada nasabah, bank syariah harus tetap berpedoman kepada syariat Islam (antara lain tidak mengandung unsur maisir, gharar, dan riba serta bidang usahanya harus halal). Adupun yang dimaksud dengan aspek ekonomi adalah mempertimbangkan perolehan keuntungan baik bagi bank syariah maupun bagi nasabah (Muhammad, 2005: 16).

Dengan memperhatikan aspek ekonomi tersebut, pembiayaan berdasarkan Prinsip Syariah merupakan penyediaan uang atau tagihan yang dipersamakan dengan itu berdasarkan persetujuan atau kesepakatan antara bank dengan pihak lain yang mewajibkan pihak yang dibiayai untuk mengembalikan uang atau tagihan tersebut setelah jangka waktu tertentu dengan imbalan atau bagi hasil (UU Republik Indonesia No. 10 Tahun 1998). Dalam Undang-undang nomor 21 tahun 2008 tentang Perbankan Syariah Bab I Pasal 1 ayat 25 menjelaskan Pembiayaan adalah penyediaan dana atau tagihan yang dipersamakan dengan itu berupa:

1. transaksi bagi hasil dalam bentuk mudharabah dan musyarakah;

2. transaksi sewa-menyewa dalam bentuk ijarah atau sewa beli dalam bentuk ijarah muntahiya bittamlik;

3. transaksi jual beli dalam bentuk piutang murabahah, salam, dan istishna';

4. transaksi pinjam meminjam dalam bentuk piutang qardh; dan

5. transaksi sewa-menyewa jasa dalam bentuk ijarah untuk transaksi multijasa berdasarkan persetujuan atau kesepakatan antara Bank Syariah dan/atau UUS dan pihak lain yang mewajibkan pihak yang dibiayai dan/atau diberi fasilitas dana untuk mengembalikan dana tersebut setelah jangka waktu tertentu dengan imbalan ujrah, tanpa imbalan, atau bagi hasil (UU Republik Indonesia No. 21 Tahun 2008).

Pembiayaan sebagai salah satu bentuk produk Perbankan Syariah tentunya harus memiliki tujuan untuk 
kebaikan umat, diantara tujuan tersebut adalah:

1. Meningkatkan ekonomi umat; Masyarakat yang tidak mendapatkan akses secara ekonomi, dengan adanya pembiayaan mereka dapat melakukan akses ekonomi sehingga dapat meningkatkan taraf ekonominya.

2. Tersedianya dana bagi peningkatan usaha; Melalui aktifitas pembiayaan, para pengusaha memperoleh dana tambahan untuk mengembangkan usahanya.

3. Meningkatkan produktifitas; Melalui dana pembiayaan, dapat memberikan peluang bagi masyarakat usaha untuk meningkatkan produksinya, sebab upaya produksi tidak akan dapat jalan tanpa adanya dana.

4. Membuka lapangan kerja baru; Dengan dibukanya sektor-sektor usaha melalui penambahan dana pembiayaan dapat menyerap tenaga kerja, hal ini berarti manambah atau membuka lapangan kerja baru (Muhammad, 2005: 17).

Dalam hal penyaluran dana, konsep pembiayaan pada perbankan syariah tidak terlalu berbeda dengan konsep kredit di perbankan konvensional, yang menjadi perbedaan antara kredit yang diberikan bank konvensional dengan pembiayaan yang diberikan oleh bank syariah adalah terletak pada keuntungan yang diharapkan. Bagi bank konvensional keutungan yang diperolah melalui bunga sedangkan bank syariah berupa imbalan atau bagi hasil (Kasmir, 2002: 73).
C. Produk Pembiayaan Bank Syariah

Secara garis besar produk pembiayaan syariah terbagi ke dalam tiga katagori yang dibedakan berdasarkan tujuan penggunaannya, yaitu (1) transaksi pembiayaan yang ditujukan untuk memiliki barang dilakukan dengan menggunakan prinsip jual beli, (2) transaksi pembiayaan yang ditujukan untuk mendapatkan jasa dilakukan dengan menggunakan prinsip sewa serta (3) transaksi pembiayaan untuk usaha kerja sama yang ditujukan untuk mendapatkan sekaligus barang dan jasa dilakukan dengan menggunakan prinsip bagi hasil (Naja, 201l: 4l).

\section{Prinsip Bagi Hasil}

Pembiayaan dengan prinsip bagi hasil diimplementasikan ke dalam dua bentuk pembiayaan yaitu pembiayaan mudharabah dan pembiayan musyarakah;

a. Pembiayaan Mudharabah adalah akad kerja sama suatu usaha antara pihak pertama (malik, shahibul mal, atau Bank Syariah) yang menyediakan seluruh modal dan pihak kedua ('amil, mudharib, atau Nasabah) yang bertindak selaku pengelola dana dengan membagi keuntungan usaha sesuai dengan kesepakatan yang dituangkan dalam Akad, sedangkan kerugian ditanggung sepenuhnya oleh Bank Syariah kecuali jika pihak kedua melakukan kesalahan yang disengaja, lalai atau menyalahi perjanjian.

b. Musyarakah adalah Akad kerja sama di antara dua pihak atau lebih untuk suatu usaha tertentu yang masing-masing pihak memberikan porsi dana dengan 
ketentuan bahwa keuntungan akan dibagi sesuai dengan kesepakatan, sedangkan kerugian ditanggung sesuai dengan porsi dana masing-masing.

\section{Prinsip Jual Beli}

Mekanisme jual beli merupakan upaya yang dilakukan dengan pola transfer of property serata tingkat keuntungan bank ditentukan di depan yang menjadi harga jual barang (Suwiknyo, 2010: 15).

Dalam praktik kegiatan usaha penyaluran dana perbankan syariah, produk yang berkaitan dengan akad jual beli adalah pembiayaan murabahah, pembiayaan salam dan pembiayaan istishna (Naja, 2011: 43)

a. Murabahah adalah akad Pembiayaan suatu barang dengan menegaskan harga belinya kepada pembeli dan pembeli membayarnya dengan harga yang lebih sebagai keuntungan yang disepakati.

b. Salam adalah akad Pembiayaan suatu barang dengan cara pemesanan dan pembayaran harga yang dilakukan terlebih dahulu dengan syarat tertentu yang disepakati.

c. Istisna adalah akad penyediaan dana dalam rangka memindahkan hak guna atau manfaat dari suatu barang atau jasa berdasarkan transaksi sewa, tanpa diikuti dengan pemindahan kepemilikan barang itu sendiri

\section{Prinsip Sewa (Ujrah)}

perbankan

Prinsip sewa yang dilakukan diimplementasikan ke dalam dua bentuk produk yaitu ijaroh dan ijaroh muntahiya bittamlik. a. Ijarah adalah akad penyediaan dana dalam rangka memindahkan hak guna atau manfaat dari suatu barang atau jasa berdasarkan transaksi sewa dengan opsi pemindahan kepemilikan barang.

b. Ijarah muntahiya bittamlik adalah akad penyediaan dana dalam rangka memindahkan hak guna atau manfaat dari suatu barang atau jasa berdasarkan transaksi sewa dengan opsi pemindahan kepemilikan barang (Rifqi, 2008: 40).

\section{Risiko Pembiayaan}

Dalam pengelolaannya, pembiayaan merupakan produk yang memiliki tingkat risiko cukup tinggi akibat nasabah pembiayaan yang gagal bayar. Pembiayaan bermasalah adalah keadaan dimana nasabah dalam hal ini debitur tidak mampu membayar sebagian atau seluruh sejumlah uang dari harga yang disepakati dengan waktu melampaui batas pembayaran atau angsuran yang telah disepakati.

Penilaian kualitas pembiayaan/kredit perbankan terbagi menjadi lima katagori, yaitu:

1. Lancar yaitu apabila memenuhi pembayaran angsuran sesuai kesepakatan.

2. Dalam perhatian khusus (special mention) yaitu apabila terdapat tunggakan belum melampaui 90 hari;

3. Kurang Lancar (substandard) yaitu apabila terdapat tunggakan angsuran pokok dan/ atau bunga yang telah melampaui 90 hari

4. Diragukan (doubtful) yaitu apabila terdapat tunggakan angsuran telah melampaui 180 hari

5. Kredit Macet yaitu apabila terdapat tunggakan angsuran pokok dan/atau 
bunga yang telah melampaui 270 hari (Peraturan Bank Indonesia Nomor: 7/2/PBI/2005 Pasal 12 ayat 3).

Dalam oprasional penyaluran pembiayaan, terdapat beberapa unsur yang saling keterkaian, pertama adalah kepercayaan dimana pihak bank mempercayai bahwa pembiayaan yang diberikan baik dalam bentuk uang, jasa maupun barang akan benar-benar dapat dibayar dan diterima kembali oleh bank dalam jangka waktu yang telah ditentukan. Kedua kesepakatan penyaluran pembiayaan yang dituangkan dalam akad pembiayaan dan ditandatangani oleh kedua belah pihak. Ketiga jangka waktu yakni waktu pengambilan pembiayaan yang telah disepakati. Keempat risiko yakni kerugian akibat penyaluran pembiayaan seperti ketika terjadinya slide streaming, lalai dan kesalahan yang sengaja, maupun penyembunyian keuntungan nasabah (Antonio, 2001: 49).

Risiko pembiayaan sering dikaitkan dengan risiko gagal bayar. Risiko ini mengacu pada potensi kerugian yang dihadapi bank ketika pembiayaan yang diberikan kepada debitur macet. Dimana debitur tidak mampu memenuhi kewajiban mengembalikan modal yang diberikan oleh bank. Selain pengembalian modal, risiko ini juga mencakup ketidak mampuan debitur menyerahkan porsi keuntungan yang seharusnya diperoleh oleh bank yang telah disepakati diawal.

Risiko pembiayaan merupakan risiko yang terjadi akibat kegagalan pihak lawan (counterparty) memenuhi kewajiban. Risiko pembiayaan dapat bersumber dari berbagai aktifitas fungsional bank seperti pembiayaan, treasury dan investasi, dan dana pembiayaan perdagangan, yang tercatat dalam banking book maupun trading book (Rivai, 2008: 633).

Faktor intern bank yang dapat menyebabkan pembiayaan bermasalah dapat berupa analisis yang dilakukan oleh pejabat bank kurang tepat, sehingga tidak dapat memprediksi apa yang akan terjadi dalam kurun waktu selama jangka waktu kredit, adanya kolusi antara pejabat bank yang menangani kredit dan nasabah, sehingga bank memutuskan kredit yang tidak seharusnya diberikan, keterbatasan pengetahuan pejabat bank terhadap jenis usaha debitur sehingga tidak dapat melakukan analisis kredit dengan tepat dan akurat, campur tangan terlalu besar dari pihak atasan sehingga petugas tidak independen dalam memutuskan kredit seta lemahnya dalam melakukan pembinaan dan monitoring pembiayaan.

Faktor ekstern yang dapat menyebabkan pembiayaan bermasalah dapat berupa debitur dengan sengaja tidak melakukan pembayaran angsuran, penyelewengan menggunakan dana kredit tidak sesuai dengan tujuan penggunaan, adanya unsur ketidak sengajaan seperti bencana alam ataupun ketidakstabilan perekonomian Negara sehingga inflasi tinggi (Ismail, 2011: 224-225).

Gejala adanya pembiayaan bermasalah dapat terdeteksi ketika terjadinya penyimpangan dari berbagai ketentuan dalam perjanjian kredit, penurunan kondisi keuangan perusahaan, frekuensi pergantian pimpinan dan tenaga inti, penyajian bahan masukan secara tidak benar, menurunnya sikap kooperatif debitur, penurunan nilai jaminan yang disediakan serta problem keuangan atau pribadi (Siswanto, 2007: 173). 


\section{E. Pengendalian dan Pencegahan Risiko Pembiayaan}

Untuk mengendalikan risiko pembiayaan yang dapat berakibat kerugian, lembaga perbankan dapat menerapkan standar pengendalian risiko sebagai berikut:

l. Bank harus menetapakan suatu sistem penilaian yang idependen dan berkelanjutan terhadap efektifitas penerapan proses manajemen risiko pembiayaan.

2. Bank harus memastikan bahwa satuan kerja pembiayaan dan transaksi pembiayaan telah dikelola secara memadai dan eksposur risiko pembiayaan tetap konsisten dengan limit yang ditetapkan dan memenuhi standar kehati-hatian.

3. Bank harus memiliki prosedur pengelolaan penangan pembiayaan bermasalah, termasuk sistem deteksi pembiayaan bermasalah secara tertulis dan menerapkannya secara efektif. Apabila bank memiliki pembiayaan bermasalah yang cukup signifikan, bank harus memisahkan fungsi penyelesaian pembiayaan bermasalah tersebut dengan fungsi yang memutuskan penyaluran pembiayaan (Rivai, dkk, 2010: 974).

Selain menerapkan standar pengendalian risiko, pencegahan risiko pembiayaan juga dilakukan melalui peganalisaan terhadap character yaitu penilaian terhadap karakter atau kepribadian calon penerima pembiayaan dengan tujuan untuk memperkirakan kemungkinan bahwa penerima pembiayaan dapat memenuhi kewajibannya, capacity yaitu penilaian kemampuan penerima pembiayaan untuk melakukan pembayaran. Kemampuan diukur dengan catatan prestasi penerima pembiayaan di masa lalu yang didukung dengan pengamatan di lapangan atas sarana usahanya seperti toko, karyawan, alat-alat, pabrik serta metode kegiatan, capital yaitu penilaian terhadap kemampuan modal yang dimiliki oleh calon penerima pembiayaan yang diukur dengan posisi perusahaan secara keseluruhan yang ditujukan oleh rasio finansial dan penekanan pada komposisi modalnya, collateral yaitu jaminan yang dimiliki calon penerima pembiayaan. Penilaian ini bertujuan untuk lebih meyakinkan bahwa jika suatu resiko kegagalan pembayaran tercapai terjadi, maka jaminan dapat dipakai sebagai pengganti dari kewajiban, condition yakni bagaimana Bank Syariah melihat kondisi ekonomi yang terjadi di masyarakat secara spesifik melihat adanya keterkaitan dengan jenis usaha yang dilakukan oleh calon penerima pembiayaan, syariah yakni penilaian yang dilakukan untuk menegaskan bahwa usaha yang akan dibiayai benarbenar usaha yang tidak melanggar syariah (Al-Ma'soem, 2004: 7).

\section{F. Mengatasi Risiko Pembiayaan} Bermasalah

Pembiayaan bermasalah merupakan suatu keadaan dimana nasabah sudah tidak sanggup membayar sebagian atau atau seluruh kewajibannya kepada bank seperti yang telah diperjanjikan sehingga akan berakibat pada kerugian bank, yaitu kerugian karena tidak diterimanya kembali dana yang telah disalurkan maupun pendapatan yang tidak dapat diterima (Ismail, 201l: 224).

Dalam hal terdapat pembiayaan bermasalah, upaya penyelesaian yang dapat dilakukan pihak bank dapat berupa rescheduling, reconditioning, 
restructuring, penyelesaian melalui jaminan serta hapus buku dan atau hapus tagih.

1. Penjadualan kembali (rescheduling), yaitu perubahan jadwal pembayaran kewajiban nasabah atau jangka waktunya;

2. Persyaratan kembali (reconditioning), yaitu perubahan sebagian atau seluruh persyaratan pembiayaan, piutang dan atau Ijarah yang tidak terbatas pada perubahan jadual pembayaran, jangka waktu, dan atau persyaratan lainnya sepanjang tidak menyangkut perubahan maksimum saldo pembiayaan, piutang dan atau Ijarah;

3. Penataan kembali (restructuring), yaitu perubahan persyaratan pembiayaan, piutang dan atau ijarah. Penataan kembali (restructuring) pembiayaan/kredit diberikan terhadap debitur yang mengalami kesulitan pembayaran pokok dan atau bunga kredit namun masih memiliki prospek usaha yang baik dan mampu memenuhii kewajiban setelah kredit direstrukturisasi (Peraturan Bank Indonesia Nomor: 7/2/PBI/2005 Pasal $1)$.

Restrukturisasi pembiayaan pada Bank Syariah dan Unit Usaha Syariah dapat dilaksanakan dengan menerapkan prinsip kehati-hatian. Bank wajib menjaga dan mengambil langkah-langkah agar kualitas pembiayaan setelah direstrukturisasi dalam keadaan lancar. Bank dilarang melakukan restrukturisasi pembiayaan dengan tujuan menghindari penurunan penggolongan kualitas pembiayaan, pembentukan perhitungan penyisihan penghapusan asset (PPA) yang lebih besar; atau penghentian pengakuan pendapatan margin atau ujrah secara akrual (OJK, 2014: 132).

Restrukturisasi pembiayaan hanya dapat dilakukan atas dasar permohonan secara tertulis dari nasabah. Restrukturisasi pembiayaan hanya dapat dilakukan untuk nasabah yang mengalami penurunan kemampuan pembayaran namun masih terdapat sumber pembayaran angsuran yang jelas dari nasabah dan mampu memenuhi kewajiban setelah restrukturisasi (OJK, 2014: 132).

$$
\text { Restrukturisasi dapat }
$$

dilakukan dengan berbagai cara, yaitu:

a. Penambahan dana BPRS, Konversi pembiayaan menjadi piutang dan atau sebaliknya, Konversi pembiayaan atau piutang menjadi Ijarah (PBI Nomor: 6/18/PBI/2004 Bab l Pasal 1)

b. Modifikasi persyaratan kredit dapat dilakukan melalui penurunan suku bunga kredit, Perpanjangan jangka waktu kredit, pengurangan tunggakan bunga kredit serta pengurangan jumlah pokok kredit

c. Penambahan fasilitas kredit yang dapat diberikan kepada debitur yang memperoleh kredit investasi/kredit modal kerja dengan tujuan agar usahanya menjadi lancar sehingga dapat mengembalikan kewajibannya.

d. Pengambilalihan agunan/asset yang akan dilakukan bila debitur sudah tidak sanggup membayar kewajibannya, dan debitur kooperatif untuk menyelesaikan 
kewajibannya dengan menyerahkan agunannya.

e. Konversi kredit yaitu merupakan konversi pinjaman debitur dalam bentuk penyertaan modal pada perusahaan debitur, sehingga konversi kredit dilakukan dengan mendapat saham perusahaan debitur (Ismail, 2011: 238-249).

\section{Penyelesaian Melalui Jaminan}

Penyelesaian melalui jaminan merupakan penyelesaian pembiayaan melalui penjualan barang-barang yang dijadikan jaminan dalam rangka pelunasan utang. Penyelesaian melalui jaminan dilakukan terhadap pembiayaan yang memang benar-benar menurut bank sudah tidak dapat lagi dibantu untuk disehatkan kembali atau usaha nasabah yang sudah tidak memiliki prospek untuk dikembangkan.

Jenis agunan yang dapat diakui sebagai jaminan pembiayaan adalah surat Berharga dan saham yang aktif diperdagangkan di bursa efek di Indonesia atau memiliki peringkat investasi dan diikat secara gadai, tanah, rumah tinggal dan gedung yang diikat dengan hak tanggungan, pesawat udara atau kapal laut dengan ukuran di atas 20 (dua puluh) meter kubik yang diikat dengan hipotek serta kendaraan bermotor dan persediaan yang diikat secara fidusia (Peraturan Bank Indonesia Nomor: 7/2/PBI/2005 Pasal 46).

Lembaga keuangan syariah (LKS) dapat melakukan penyelesaian murabahah bagi nasabah yang tidak bisa menyelesaikan/melunasi pembiayaannya dengan ketentuan obyek urabahah atau jaminan lainnya dijual oleh nasabah kepada atau melalui LKS dengan harga pasar yang disepakati, nasabah melunasi sisa utangnya kepada LKS dari hasil penjualan, apabila hasil penjualan melebihi sisa utang maka LKS mengembalikan sisanya kepada nasabah, apabila hasil penjualan lebih kecil dari sisa utang maka sisa utang tetap menjadi utang nasabah, serta apabila nasabah tidak mampu membayar sisa utangnya, maka LKS dapat membebaskannya (Fatwa Dewan Syari'ah Nasional No. 47/DSN-MUI/II/2005).

5. Write Off (Hapus Buku dan Hapus Tagih)

Hapus buku merupakan pinjaman macet yang tidak dapat ditagih lagi dihapusbukukan dari neraca (on-balance sheet) dan dicatat pada rekening administratif (of balance sheet). Penghapusbukuan pinjaman macet tersebut dibebankan pad akun penyisihan penghapusan aktiva produktif. Meskipun pinjaman macet tersebut telah dihapusbukukan hal ini hanya bersifat administratif sehingga penagihan terhadap debitur tetap dilakukan. Penghapusbukuan kredit (hapus buku) merupakan tindakan administratif bank untuk menghapus buku kredit macet dari neraca sebesar kewajiban debitur tanpa menghapus hak tagih bank kepada debitur, sedangkan penghapusan hak tagih kredit (hapus tagih) merupakan tindakan bank menghapus semua kewajiban debitur yang tidak dapat diselesaikan (http://rinaldytuhumury.blogspot.co.id). 
Ketentuan tentang hapus buku dan atau hapus tagih pada Peraturan bank Indonsia nomor: 7/2/pbi/2005 tentang penilaian kualitas aktiva bank umum Pasal 70 adalah hapus buku dan atau hapus tagih hanya dapat dilakukan terhadap penyediaan dana yang memiliki kualitas Macet, hapus buku tidak dapat dilakukan terhadap sebagian penyediaan dana (partial write off), hapus tagih dapat dilakukan baik untuk sebagian atau seluruh penyediaan dana. Hapus tagih terhadap sebagian penyediaan dana hanya dapat dilakukan dalam rangka Restrukturisasi Kredit atau dalam rangka penyelesaian Kredit.

\section{G. Kesimpulan}

Dari pembahasan di atas dapat disimpulkan bahwa manajemen penyelesaian pembiayaan bermasalah dapat dilakukan dengan: pertama, menerapkan standar pengendalian risiko, pencegahan risiko pembiayaan juga dilakukan melalui peganalisaan terhadap character yaitu penilaian terhadap karakter atau kepribadian calon penerima pembiayaan dengan tujuan untuk memperkirakan kemungkinan bahwa penerima pembiayaan dapat memenuhi kewajibannya, capacity yaitu penilaian kemampuan penerima pembiayaan untuk melakukan pembayaran. Kedua, dapat dilakukan dengan langkahlangkah (1) penjadualan kembali (rescheduling), (2) persyaratan kembali (reconditioning), (3) penataan kembali (restructuring), (4) penyelesaian melalui jaminan, dan (5) write off (hapus buku dan hapus tagih).

\section{DAFTAR PUSTAKA}

Al-Ma'soem BPRS PNM. 2004. Kebijakan Manajemen Pembiayaan Bank Syariah. Bandung: BPRS PNM Al-Ma'soem.

Anshori, Abdul Ghafur. 2008. Tanya Jawab Perbankan Syari'ah. Yogyakarta: Uii Press.

Antonio, Muhammad Syafi'i. 2001. Bank Syariah Dari Teori Ke Praktik. Jakarta: Gema Insani.

Arifin, Zainul. 2005. Dasar-Dasar Manajemen Bank Syariah. Jakarta: Pustaka Alfabet.

OJK. 2014. Booklet Perbankan Indonesia Edisi 1. Jakarta: Departemen Perizinan Dan Informasi Perbankan Otoritas Jasa Keuangan.

Djumhana. 2000. Hukum Perbankan Di Indonesia. Bandung: Citra Aditya Bakti.

Fatwa Dewan Syari'ah Nasional No. 47/DSN-MUI/II/2005 Tentang Penyelesaian Piutang Murabahah Bagi Nasabah Tidak Mampu Membayar

Ismail. 2011. Akuntansi Bank: Teori Dan Aplikasi Dalam Rupiah. Jakarta: Kencana Prenada Media Group.

Kasmir. 2002. Dasar-Dasar Perbankan. Jakarta: PT. Raja Grafindo Persada.

Kasmir 2004. Pemasaran Bank. Jakarta: Kencana.

Muhammad. 2008., Manajemen Pembiayaan Bank Syariah. Yogyakarta: UPP AMP YKPN.

Muhammad, Rifqi. 2008. Akuntansi Keuangan

Syari'ah. Yogyakarta: P3EI Press. 
Naja, H. R. Daeng. 2011. Akad Bank Syariah. Surat Keputusan Direktur Bank Indonesia Yogyakarta: Pustaka Yustisia.

Peraturan Bank Indonesia Nomor: 6/18/PBI/2004 tentang Kualitas Sutedi, Adrian. 2009. Perbankan Syari'ah: Aktiva Produktif Bagi Bank Tinjauan Dan Beberapa Segi Hukum. Perkreditan Rakyat Syariah Bogor: Ghalia Indonesia.

Peraturan Bank Indonesia Nomor: Suwiknyo, Dwi. 2010. Jasa-Jasa Perbankan 7/2/PBI/2005 Tentang Penilaian Kualitas Aktiva Tetap Bank Umum

Rivai, Veithzal. 2008. Islamic Financial Triandaru, Sigit dan Totok Budisantoso. Management. Jakarta: Raja Grafinda Persada.

Rivai, Veithzal Dan Arviyan Arifin. 2010. Islamic Banking: Sebuah Teori, Konsep, dan Aplikasi. Jakarta: Bumi Aksara.

Rolan M. 2010. Kamus Istilah Ekonomi Popular. Jakarta: Penerbit George Media.

Sinungan, Muchdarsyah. 2000. Manajemen Dana Bank. Jakarta: PT. Bumi Aksara.

Siswanto, Sutojo. 2007. The Management Of Commercial Bank. Jakarta: Damar Mulia Pustaka. Syariah. Yogyakarta: Pustaka Pelajar. 2006. Bank Dan Lembaga Keuangan Lain. Jakarta: Salemba Empat.

UU Republik Indonesia No. 10 Tahun 1998 Tentang Perbankan

UU Republik Indonesia No. 21 Tahun 2008 Tentang Perbankan Syariah

Wahyudi, Imam Dkk. 2013. Manajemen Risiko Bank Islam. Jakarta: Salemba Empat.

Public Sector Accounting, Bussiness And Auditing: Penyisihan Kerugian Dan Penghapusbukuan, http://rinaldytuhumury.blogspot.co.id, diakses tanggal 5 Mei 2016 